\title{
Measuring Form, Ornament and Materiality in Sinan's Kılıç Ali Paşa Mosque: an Analysis Using Fractal Dimensions
}

\author{
Michael J. Ostwald • Özgür Ediz
}

\begin{abstract}
The Kılıç Ali Paşa Mosque in Istanbul was completed in the late sixteenth century and it is today regarded as one of architect Sinan's most important works. Like many of Sinan's designs it has been the subject of detailed analysis in the past, with historians offering theories to explain its visual properties and how they differ from those of his previous works. However, such theories have remained largely untested because of the difficulty of quantitatively analysing the building's intricate formal, ornamental and material properties. The present paper uses computational fractal analysis to overcome this problem. This method, as it is applied in the paper, derives a non-integer measure of the characteristic complexity of three hierarchical layers in visual information in the facades of the Kılıç Ali Paşa Mosque. Through this process the paper not only provides important quantitative results which can be used to test past theories about the building, but these new measures are then compared with those that have previously been developed, using the same method, for Sinan's Süleymaniye Mosque.
\end{abstract}

\section{Introduction}

Architect Mimar Sinan's Kılıç Ali Paşa Mosque was constructed between 1578 and 1580 in Istanbul, Turkey. With its short nave and monumental central dome, the Kılıç Ali Paşa Mosque is widely regarded as being modelled on nearby Hagia Sophia (Ayasofya). One of Sinan's last major designs, the Kılıç Ali Paşa Mosque is

\footnotetext{
M. J. Ostwald $(\bowtie)$

School of Architecture and Built Environment, The University of Newcastle,

Callaghan, NSW 2308, Australia

e-mail: Michael.Ostwald@newcastle.edu.au

Ö. Ediz

Department of Architecture, Uludag University, Bursa, Turkey

e-mail: ozgurediz@gmail.com
} 


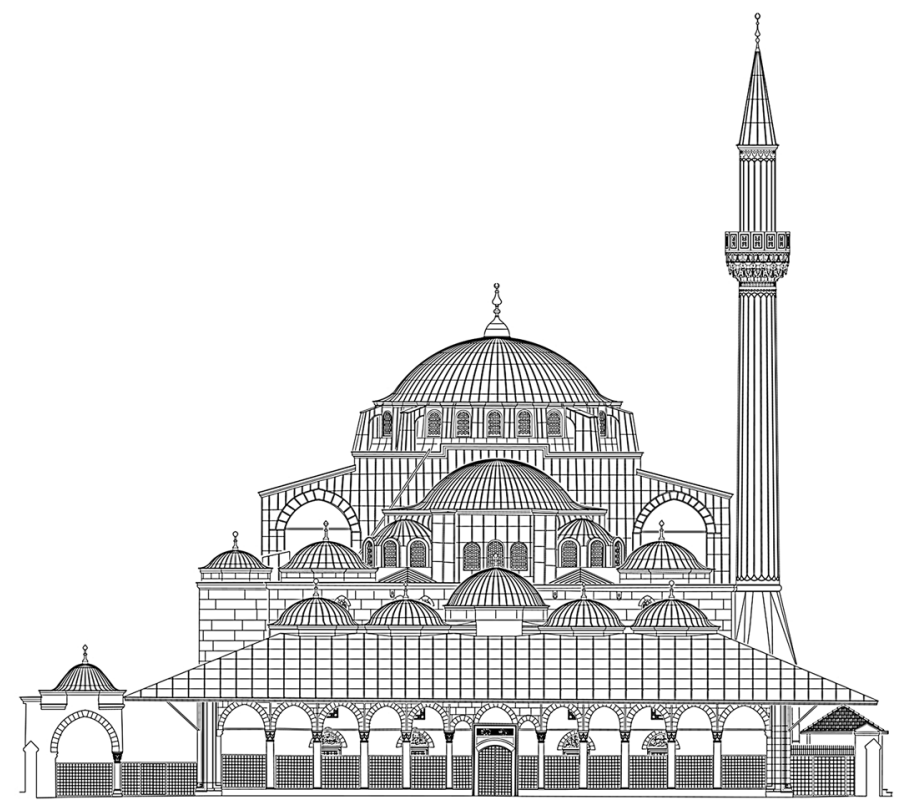

Fig. 1 Kılıç Ali Paşa Mosque, north west elevation

revered for its complex tangible and intangible properties including its use of form and proportion to symbolise the universe and to celebrate the cultural and architectural achievements of Islam (Fig. 1). For over a century architectural scholars have closely examined this building using intuitive and conceptual approaches and offered several theories to explain its importance in Sinan's body of work (Goodwin 1971; Stratton 1972; Kuran 1986; Freely 1992; Rogers 2006). These studies employ a combination of historical and phenomenological methods to interpret the physical and material properties of the building. The advantage of such an approach is that it is attuned to the figurative, poetic or sensory properties of the mosque. Its difficulty is that it has no quantitative basis and thus the arguments promulgated by historians and theorists about the Kılıç Ali Paşa Mosque cannot be replicated or tested. For example, in past published research Sinan's architecture is typically interpreted as being, relative to that of his contemporaries, less reliant on ornament and more on form (Kuban 1987; Necipoğlu 2005). Similarly, the role of form in the Kılıç Ali Paşa Mosque is potentially considered less significant than it is in Sinan's mid-career masterwork, the Süleymaniye Mosque (Burelli 1988; Freely 1992). Such qualitative claims about the mosque design, while potentially true, are difficult to test without using an alternative, quantitative approach to examining complex geometric forms. One such alternative approach is to measure the visual complexity of Sinan's architecture using a method derived from the mathematics of non-integer dimensions: computational fractal analysis.

The computational fractal analysis approach is used to measure the characteristic visual complexity of an image or object. In a sense, it measures the density and distribution of geometric information and reports this as a single result, the fractal 
dimension $(D)$. The technique for measuring the fractal dimension of an object was developed separately by the mathematicians Benoit Mandelbrot (1977) and Richard Voss (1986) and it has since become the standard approach in many fields (Huang et al. 1994; Camastra 2003; Neal and Russ 2012). The architectural and urban application of fractal analysis was first demonstrated in the 1990s (Batty and Longley 1994; Bovill 1996) before being applied to a growing body of architectural cases in more recent years (Bechhoefer and Appleby 1997; Lorenz 2003; BurkleElizondo et al. 2014; Gözübüyük et al. 2006; Ostwald et al. 2008; Vaughan and Ostwald 2011). The optimal computational version of this method and its variables - its subject material, mathematical basis and algorithmic process-has been identified in recent architectural applications (Ostwald 2013; Ostwald and Vaughan 2013a, b). However, simply measuring the fractal dimension of the elevations of the K1lıç Ali Paşa Mosque-despite being an original and technically complex contribution to Sinan scholarship_will not directly assist the assessment of past interpretations of his architecture. For this reason, the present paper adopts a specific methodological variation to undertake an analysis of measures derived from three key layers of information that are present in the façade of Sinan's mosque (Ediz and Ostwald 2012).

This paper presents the results of the measurement of the visual complexity of three cumulative layers of geometric information-(a) form, (b) form and ornament and (c) form, ornament and materiality - in the facades of the Kılıç Ali Paşa Mosque. These results are then compared with equivalent measures developed previously from the facades of Sinan's Süleymaniye Mosque using the same method (Ediz and Ostwald 2012). Through this process the paper provides a set of new, mathematically-derived measurements from which arguments about trends in Sinan's architecture can be revisited and assessed. The paper also considers what these two sets of results might begin to reveal about changes that occurred over time in Sinan's approach to design.

The paper commences with an overview of Sinan's architecture and career before introducing the Kılıç Ali Paşa Mosque and kulliye (complex), its history and architectural features. Thereafter, the computational fractal analysis method is described. Because this method has been widely used in the past, and multiple recent publications exist which outline its application, the present paper only provides an overview of the standards and settings used, along with references to works that offer more detailed explanations. Thereafter, the three layers of information being analysed and measured in each façade are defined and illustrated. The results of the fractal analysis of the Kılıç Ali Paşa Mosque are then presented and reviewed in isolation, before being compared with those derived from the Süleymaniye Mosque and kulliye.

Before progressing, there are several factors associated with the research that must be clarified. First, the scope of the paper is restricted to the mathematically measurable properties of a complex and culturally significant building. While the Kılıç Ali Paşa Mosque has many spiritual and symbolic qualities, they are not directly considered in this paper. Second, the Kılıç Ali Paşa Mosque is an integral part of a larger kulliye that includes several secondary structures and elements which were designed by Sinan as an extension of the mosque. Thus, while the paper 
talks about measuring the fractal dimension of the mosque, it is actually measuring the properties of the mosque, its immediate walled enclosure and the fountain forecourt and mausoleum structure that are within the same space as the mosque. There is one complicating factor in this decision; the madrasa (educational facility) which adjoins the south west interior wall of the kulliye was most likely not designed by Sinan. However, one of its walls is part of the mosque enclosure that is measured in this paper. Rather than attempting to artificially remove or replace this element we have included it as part of the overall measuring process. In practice the madrasa wall is only visible in a short section of the north east elevation.

\section{Sinan the Architect}

Sinan was born during the last decade of the 15th century in the village of Agirnas, in the Kayseri province, in what is today central Turkey. He was recruited into the devshirme system and learned carpentry and construction as a member of the Janissary Corps (Günay 2009). During the reign of Süleyman the Magnificent, Sinan served in various military and engineering roles and was appointed to the position of chief architect. Sinan remained in this post for almost 50 years, being responsible for the design, construction and restoration of over 400 buildings. The four most famous of these designs have come to represent critical stages in his career. The first, from Sinan's early or apprenticeship period, is the Shehzade Mosque in Istanbul, the second is the Süleymaniye Mosque in Istanbul, the third is the Selimiye Mosque in Edirne and the final, from the last stage of his career, is the Kılıç Ali Paşa Mosque.

Sinan's buildings are regarded as projecting a powerful presence that is evoked not only through their scale and function (as places of worship) but also through the way they are constructed from relatively unadorned, Phileban or Neo-Platonic geometric forms. Kuban $(1987,1997)$ proposes that one of the key characteristics of Sinan's architecture rests in the way form is privileged over other, more decorative, elements. For example, whereas many mosques of the era were richly decorated, Sinan's design strategy relied upon geometric forms that clearly expressed the visual and formal properties of their underlying structure and which were only selectively adorned, allowing a strong sense of the materiality of the building to remain tangible. Necipoğlu (2005: p. 15) paraphrases this argument as being that in Sinan's mosques "ornament is subordinated to functional form" and "decoration (has) absolutely no influence on the architectural design".

In an attempt to understand the visual properties of Sinan's architecture, Erzen (2004) conceptualises it as consisting of a series of hierarchical layers wherein the largest scale elements (form and structure) remain distinctly articulated in the final design. This proposition suggests that the first layer of the façade is made up of over-arching formal gestures (domes, arches, walls) as well as major structural members (typically columns, beams, buttresses and frame recessed planes) along with perforations (windows and doors). This level of architectural expression is then supplemented with a layer of ornamentation which is used to control the way light falls on walls, through windows and across thresholds, and with simple spiritual motifs and inscriptions. The final level of visual presence is embodied in the 
tectonic and material properties of the design, that is, the joints in materials-which are both a reflection of the type and scale of material, be it stone, timber or terracotta-and its method of construction. Whereas in many mosques the tectonic and material properties of the design are largely hidden beneath a dense layer of ornament, in Sinan's architecture they continue to have a strong visual presence. It is this layered and hierarchical interpretation of Sinan's architecture, which is repeated in variations in many different scholarly works, that provides the basis for the approach taken in the present paper.

\section{The Kılıç Ali Pasha Mosque}

The Kılıç Ali Pasha kulliye is located on an urban site in the Tophane waterfront neighbourhood of Istanbul. It was considered fitting that a mosque designed for a grand admiral should be constructed so close to the sea, and in the vicinity of the imperial cannon foundry. Indeed, some of the land on which the kulliye is sited is thought to have once been part of the sea and in the years following its construction, further reclamation has increased its distance from the water. The complete kulliye includes a mosque, a mausoleum, a madrasa, a foundry and two bathhouses. The primary, enclosed kulliye is broadly rectangular in plan, oriented to the qibla in the south east. Within the main rectangular-walled volume, the mosque is to the northwestern part of the plan and the octagonal mausoleum is to the south east. The mosque has a longitudinal plan, a fact which some scholars have found paradoxical given Sinan's mastery of the centralised plan in his earlier Selimiye Mosque. Furthermore, Sinan's autobiographies make no mention of the madrasa, leading scholars to believe it was a later addition.

One of the most striking properties of the Kılıç Ali Pasha Mosque is that its form resembles a scaled-down variation of Hagia Sophia. Necipoğlu (2005) argues that Sinan himself chose Hagia Sophia as the model for this design, although Hagia Sophia also allegedly fascinated his patron. Many of the structural features of Hagia Sophia are repeated in the Kılıç Ali Pasha Mosque including, most notably, the central dome with its two half-domes. The obvious differences between Hagia Sophia and the Kılıç Ali Pasha Mosque are that the four minarets of the former are reduced to one in the latter, while the portico forecourt of Hagia Sophia is omitted altogether. Cut stone also replaces the brick masonry of Hagia Sophia and the interior is more lavishly decorated in the latter work.

The grand admiral and patron of the mosque, Kılıç Ali Pasha, was born Giovanni Dionigi Galeni in Calabria in 1519. Raised in a Christian family, he was captured by Ottoman pirates and placed in their service as a galley slave. Starting as an oarsman and then serving in the corsair fleet, he converted to Islam and became a reis (captain) in 1551. The skill he displayed during subsequent naval campaigns enabled him to rise further through the ranks, eventually being appointed Pasha (grand admiral) and given the title of kllıç (sword) in 1571. In this post he successfully collaborated with Grand vizier Sokullu and during Murad III's reign he oversaw construction projects at Topkapı Palace. Relying on a large team of skilled slaves to support the building process, Kılıç Ali was respected for both his strategic 
and administrative skills and he personally oversaw the construction of his own mosque. Sinan, who was 88 at the time he started this commission, may well have sought the assistance of the pasha's own architects and artisans in the design of the Tophane mosque (Necipoğlu 2005). On his death in 1587, Kılıç Ali Pasha's inheritance, which was carefully documented in multiple waqfiyyas (a deed or will), eventually passed to the sultan. This last fact is significant because details of the design and construction timeline of his kulliye can be deduced from the second of the grand admiral's waqfiyyas. For example, the waqfiiyya of May 1581 is dated to coincide with the completion of the foundation of the mosque. Further details about the chronology of the construction can be gleaned from imperial decrees including one of June 1578 where the sultan states that his grand admiral had begun the building of a Friday mosque (a public place of worship), while one of May 1579 indicates a need for lead for the mosque's construction. A submission to the Venetian Senate dated February 1579 requests 12,000 discs of bottle glass for the mosque's windows (Necipoğlu 2005).

Much of the original urban surroundings of the kulliye have since disappeared, although the public square remains. The north wall of the kulliye was moved in the 1950s to allow for the widening of an avenue in front and the present precinct wall has five gates whereas the original wall surrounding the funerary garden once included an additional gate to the mausoleum. The original domed ablution fountain is also preserved and behind the fountain courtyard is the double portico with overhanging eaves supported by wooden struts. This portico is separated from the forecourt by iron grills and a marble gate bearing a cursive thuluth inscription. Between the marble columns of the inner portico and the more diminutive supports of the outer portico is a central opening featuring a triangular hood which has been carved with calligraphy. The largest gate in the precinct wall faces the public square and it bears an inscription on its arched lunette that pays tribute to Murat III and his servant Ali Pasha.

Returning to the mosque itself, several other differences from Hagia Sophia are obvious from a closer inspection, including the lack of external buttresses (which are so visually significant in Hagia Sophia); while inside the four large angular piers are replaced by slimmer round ones in the more recent building. The stained glass windows of the qibla wall in the Kılıç Ali Pasha Mosque-restored in 1959—are complemented by large arch-shaped lunettes. Within the interior all of the inscriptions are from the Koran, emphasising a reward in heaven for those engaging in communal worship. The domed superstructure features painted inscriptions, the one on the roundel of the central hemisphere referring to the singular nature of God, in clear contrast to the allusion to the Holy Trinity found on the dome of Hagia Sophia. Other inscriptions on the pendentives, half-domes, exedras and mihrab also stress the importance of prayer and devotion and refer to the omniscience of God. Such inscriptions are not only an anticipated part of a mosque design from that era, but given the otherwise clear formal parallels to Hagia Sophia, they provide an important symbolic and liturgical counterpoint. As the inscription on the lunette of the main precinct proclaims, "if a mere servant of the sultan could produce such a work as this, what could the sultan himself achieve?" This is a clear reference not only to the glory of Islam but also to its achievements in architecture and engineering. 


\section{Research Method: Computational Fractal Analysis}

There are very few methods for the analysis of the visual properties of architecture that are capable of measuring the presence of many hundreds of thousands of lines in the façade of a complex, historic building. One approach that can be used for this purpose is fractal analysis, an accepted method for determining the characteristic visual complexity of an object or image. This method is used to calculate the fractal dimension of two-dimensional line images (Neal and Russ 2012; Ostwald 2013). Because this method analyses images of objects, the more refined the starting image, the more accurate the result. The method effectively determines the level of information present in an image, across multiple scales (analogously, from very close to more distant) and then calculates the typical spread of that information. Thus, it could be regarded as a measure of the consistency of the hierarchy of detail present in a facade. A facade may have multiple features at different scales, from grand ceremonial doors, to pilasters and carved mouldings, but the method measures the average distribution of all of these features across all scales (Bovill 1996; Lorenz 2003; Ostwald et al. 2008).

\section{Stage 1: Image Pre-Processing}

The fractal analysis method for architecture commences with an image, typically an elevation or plan. The method is known to be sensitive to inconsistent image properties and so each elevation or plan must be meticulously prepared and preprocessed, prior to analysis. For example, no symbolic graphic conventions must be present (no door-swings or hidden-line details) in the image, no representations of time or texture (shadows and abstract hatching), no entourage elements (trees, people and cars) and a consistent line weight must be used throughout. The image must then be pre-processed to ensure that only distinct lines are present, with no "fills" or greyscale elements. The image resolution must also be optimised, along with the width of lines (to a 1-pixel standard) and the framing or position of the image on its field must conform to an optimal standard (Foroutan-Pour et al. 1999; Ostwald and Vaughan 2013b). All of these processes must be followed to ensure that the final calculations are accurate and repeatable. For the present research the survey drawings provided by the Istanbul Directorate of Foundations were digitally re-traced, modified and pre-processed by the authors in accordance with these standards.

\section{Stage 2: Data Processing}

In the second stage a grid is placed over each image and each square analysed to see if there are any of the lines of that elevation drawing present in the grid. The number of boxes with detail in it is then recorded. Then a smaller grid size is overlain on the image and the same process is repeated, now at a different scale, and the number of boxes with information in them recorded. This data is then processed using the following values;

$\mathrm{N}_{(\mathrm{s} \#)}=$ the number of boxes in grid number "\#” containing some detail.

$1 / \mathrm{s} \#=$ the number of boxes in grid number "\#" at the base of the grid. 
Table 1 Methodological variables used

\begin{tabular}{|c|c|c|c|}
\hline Stage & Variable & Setting & Notes \\
\hline \multirow[t]{4}{*}{$\begin{array}{l}\text { Image pre- } \\
\text { processing }\end{array}$} & White space & $\begin{array}{l}\text { "50\% } \\
\text { increase" }\end{array}$ & $\begin{array}{l}25 \% \text { of the shortest image length is attached } \\
\text { to each side of the image to generate the } \\
\text { starting field }\end{array}$ \\
\hline & Image position & Centre-centre & $\begin{array}{l}\text { The image was centred on the field before } \\
\text { analysis }\end{array}$ \\
\hline & Line weight & $1 \mathrm{pt}$ & $\begin{array}{l}\text { Sobel edge detection was used to reduce the } \\
\text { size of all lines present in the starting } \\
\text { image to this width }\end{array}$ \\
\hline & Image resolution & $125 \mathrm{dpi}$ & $\begin{array}{l}\text { Number of 'dots per inch' in the starting } \\
\text { image }\end{array}$ \\
\hline \multirow[t]{5}{*}{ Data processing } & $\begin{array}{l}\text { Scaling coefficient } \\
(S C)\end{array}$ & $1.4142: 1$ & $\begin{array}{l}\text { This is the ratio by which successive grids } \\
\text { are reduced in size }\end{array}$ \\
\hline & $\begin{array}{l}\text { Grid disposition } \\
(G D)\end{array}$ & Edge-growth & $\begin{array}{l}\text { Successive grids for comparison were all } \\
\text { generated from the edge of the image }\end{array}$ \\
\hline & Grid comparisons & $16-17$ & $\begin{array}{l}\text { The number of grids (each reducing in size } \\
\text { by a set ratio) which were analysed for } \\
\text { each layer and for each elevation }\end{array}$ \\
\hline & Starting grid size & $0.25 l$ & $\begin{array}{l}\text { The first grid was generated by dividing the } \\
\text { shortest dimension of the field by four }\end{array}$ \\
\hline & $\begin{array}{l}\text { Statistical } \\
\text { divergence }\end{array}$ & $2 \%$ & $\begin{array}{l}\text { The closing grid size was determined by } \\
\text { using a } 2 \% \text { limit on the degree to which } \\
\text { each result diverged from the mean of the } \\
\text { previous results }\end{array}$ \\
\hline
\end{tabular}

A comparison is then made of the number of boxes with detail in the first grid $\left(N_{(\mathrm{s} 1)}\right)$ and the number of boxes with detail in the second grid $\left(N_{(\mathrm{s} 2)}\right)$. Such a comparison is made by plotting a $\log -\log \operatorname{diagram}\left[\log \left(N_{(\mathrm{s} \#)}\right)\right.$ versus $\left.\log (1 / \mathrm{s} \#)\right]$ for each grid size. The slope of the straight line produced by the comparisons- the approximate fractal dimension $(D)$ - is calculated as follows:

$$
D=\frac{\left[\log \left(N_{(s 2)}\right)-\log \left(N_{(s 1)}\right)\right]}{[\log (1 / s 2)-\log (1 / s 1)]}
$$

When this process is repeated a sufficient number of times, for multiple grid overlays on the same image, the average slope, or $D$ can be estimated.

The key factors influencing the accuracy of this estimation are the number of grid comparisons used in the process and the size of the data set analysed (that it, the number of boxes counted in the complete set of calculations). For the present research, ArchImage software (Version 1.5) was used for all processing and analysis. For each variation (explained hereafter) of each elevation, an average of 16-17 grid overlays were analysed. The methodological variables and settings used are summarised in Table 1 and explained in various publications (Bovill 1996; Foroutan-Pour et al. 1999; Lorenz 2003; Ostwald et al. 2008; Ostwald 2013). For the Kılıç Ali Paşa Mosque a total of 180 grid comparisons were calculated, recording over 846,000 data points, which were processed in the software to derive 12 separate fractal dimension measurements of the façades. 


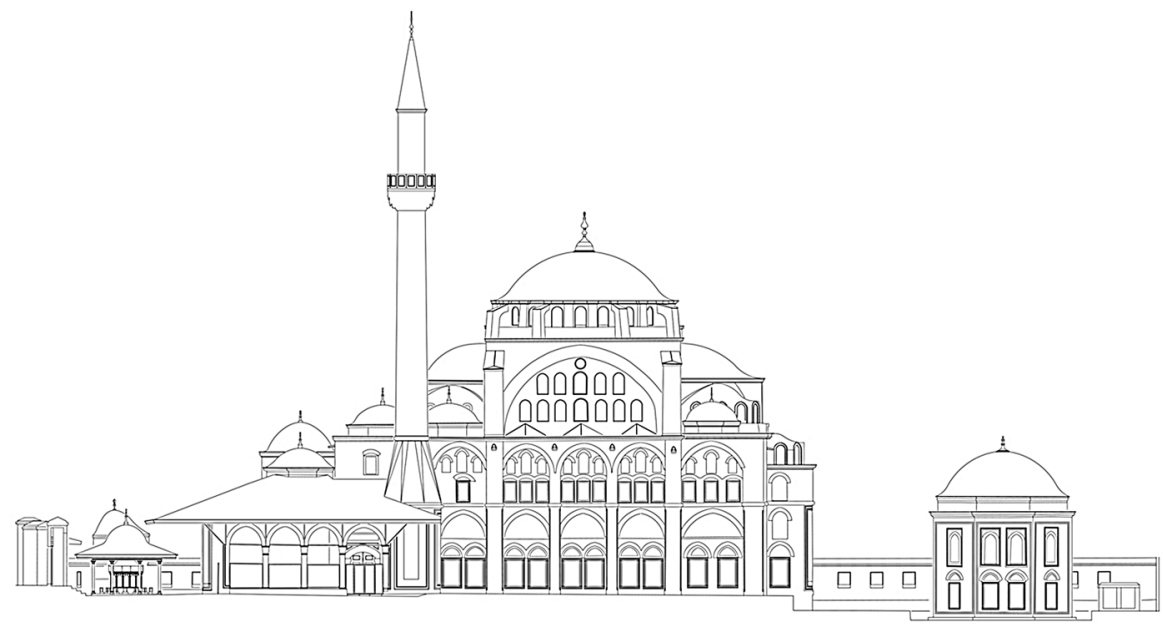

Fig. 2 Kılıç Ali Paşa Mosque, south west elevation, primary façade layer- "form”

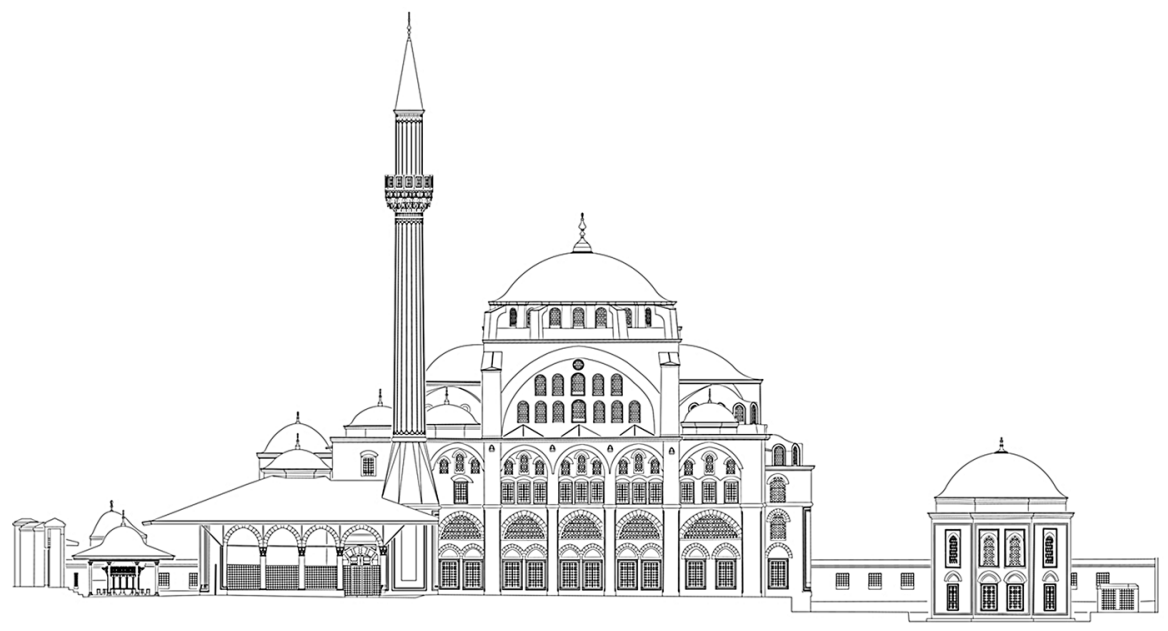

Fig. 3 Kılıç Ali Paşa Mosque, south west elevation, secondary façade layer added—- "form and ornament"

\section{Methodological Application}

A particular feature of the present analysis is that it isolates and measures three different hierarchical layers of geometric information in each façade of the K1lıç Ali Paşa Mosque. These layers correspond to the typical distinctions drawn by historians and design theorists between façade elements in Sinan's architecture (Kuban 1987, 1997; Erzen 2004; Necipoğlu 2005). For the present purpose, the three layers are called primary, secondary and tertiary and are defined as follows. 


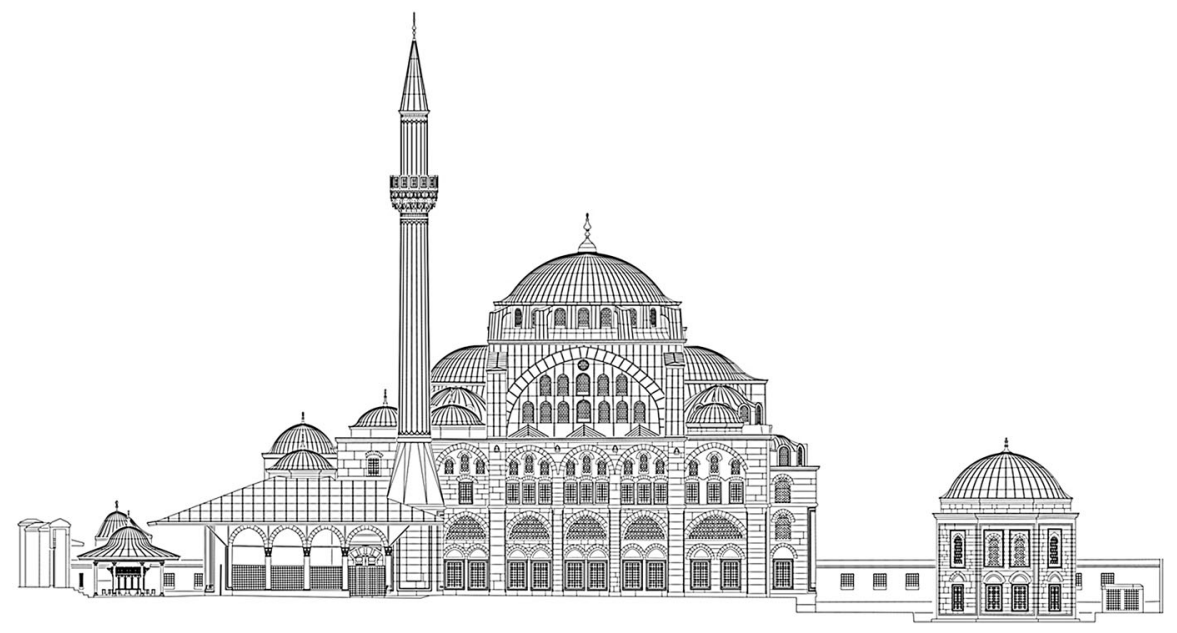

Fig. 4 Kılıç Ali Paşa Mosque, south west elevation, tertiary façade layer added—- "form, ornament and materiality"

The primary layer of façade information includes the three-dimensional volume of the building as an expression of enclosure (walls and roofs), permeability (doors and windows) and structure. In the K1lıç Ali Paşa Mosque these visual properties are largely associated with the formal expression of the structure (columns, beams, arches, vaults) and the programme (size of openings, covered walkways, enclosing walls). This level of detail could be called "form-related" (Fig. 2). The secondary layer in each facade typically comprises perforations or textures that have been cut into stone screens, the decorative bars on windows, the carved calligraphy above doors and lunette windows and the stalactite forms in and around muqarnas vaults. While many of these visual elements do serve some practical purpose, the vast majority could be considered as types of ornament. However, these elements cannot be considered in isolation from the larger forms that frame them and so this secondary layer is expressed as being the combination of form and ornament (Fig. 3). The tertiary layer of the façade adds material and tectonic properties, being mostly the joints between elements that cover larger surfaces (tiles, bricks or stone blocks). This additional layer could be considered a result of the exigencies of the construction process. Tertiary visual elements in the Kılıç Ali Paşa Mosque include the visible joints between stones, the ridges in the dome roof cladding and the lead connections between steel bars. As it is measured, this last layer combines form, ornament and materiality (Fig. 4).

While this tripartite system is in accordance with past definitions provided by historians, and its application is consistent with that of a previous mathematical study (Ediz and Ostwald 2012), the distinction between each layer is potentially a contentious one. In particular, in several instances, the differentiation between form and ornament is not always as apparent as it is between materiality and either form or ornament. For example, it might be argued that not all of the windows, openings or arched enclosures actually serve a functional purpose. Thus, some windows allow 
for light or ventilation, while others are compositional elements that have no practical purpose. This might imply that some windows should be on the form layer and others on the ornament layer. Conversely, it could be argued that some of the engaged-buttressing beneath the central dome is more ornamental than practical. While such observations are legitimate, for the present purpose a consistent approach has been taken to each type of element, rather than each instance of that element.

A further complicating factor is that the method measures lines that can, on occasion, be simultaneously part of multiple layers in the façade. For example, several variegated keystone elements above windows in Sinan's architecture protrude significantly from the façade and must be considered structural and thereby part of the form layer. Yet, these same elements are also coloured in alternating red and white masonry blocks, a clearly ornamental distinction, but the change in colouring corresponds to material joints. Thus, in this example, the same four lines that geometrically define the trapezoidal keystone element potentially serve all three layers. Such instances are rare in the large and complex facades of Sinan's work, but they do present a challenge for the method. The solution taken in the present paper is that each geometric element should be measured on the first layer it is logically a member of. Thus, in some cases, form takes precedent over ornament, which in turn takes precedent over materiality. If there were a very large number of instances where this occurs, the mathematical results might understate the significance of the latter layers. However, such instances were rare in the process.

\section{Results and Discussion}

For each façade a set of results for the three layers of information was developed: form $\left(D_{[\mathrm{F}]}\right)$, form and ornament $\left(D_{[\mathrm{FO}]}\right)$, form, ornament and materiality $\left(D_{[\mathrm{FOM}]}\right)$ (Table 2). The complete set of results for the elevations of the Kılıç Ali Paşa Mosque was then recorded (Table 3). Two additional measures were derived from this data. The first is the difference between each successive layer expressed as a fractal dimension $\left(D_{[\text {Diff }]}\right)$. For example, consider the results for the south west elevation (Table 3): the addition of ornament to the form layer accounts for a rise of $D_{\text {[Diff }]}=0.0381$, while materiality adds a further $D_{\text {[Diff }]}=0.0575$ to the result. The second derived measure is the proportion, expressed as a percentage of the complete visual presence of a façade, that is made up of each of the three elements; form, ornament and materiality. Thus, in the example of the south west elevation (Table 3), $86 \%$ of the total geometric information present in the façade is generated from form, $6 \%$ from ornament and $8 \%$ from materiality.

The complete set of results for the building indicates that the formal entry façade to the mosque, along its central longitudinal axis and through the fountain forecourt, is the most divergent. It is the least visually complex of all of the elevations in terms of form $\left(D_{[\mathrm{F}]}=1.5558\right)$ and combined form and ornament $\left(D_{[\mathrm{FO}]}=1.6137\right)$. When material joints are added, its overall visual complexity rises to the second highest of the elevations $\left(D_{[\mathrm{FOM}]}=1.7122\right)$. It is, in this sense, the least consistent, or most distinctive, of the elevations in character, having the highest overall proportion 
Table 2 Sample results for the north east elevation of the Kılıç Ali Paşa Mosque

\begin{tabular}{lrlll}
\hline North east elevation & Box size & \multicolumn{2}{l}{ Box count } \\
\cline { 3 - 5 } Iteration & & Form & Form + ornament & Form, ornament + materiality \\
\hline 1 & 5 & 30,015 & 39,798 & 53,871 \\
2 & 7 & 18,045 & 22,777 & 30,638 \\
3 & 11 & 9,110 & 10,772 & 13,975 \\
4 & 15 & 5,608 & 6,363 & 7,949 \\
5 & 21 & 3,280 & 3,569 & 4,196 \\
6 & 30 & 1,863 & 1,958 & 2,163 \\
7 & 42 & 1,037 & 1,071 & 1,139 \\
8 & 60 & 598 & 600 & 615 \\
9 & 84 & 324 & 324 & 330 \\
10 & 119 & 182 & 182 & 183 \\
11 & 169 & 104 & 104 & 104 \\
12 & 239 & 54 & 54 & 54 \\
13 & 337 & 34 & 34 & 34 \\
14 & 477 & 22 & 22 & 22 \\
15 & 675 & 15 & 15 & 15 \\
16 & 954 & 9 & 9 & 9 \\
17 & 1,349 & 4 & 4 & 4 \\
Fractal dimension $(D)$ & & $D_{[\mathrm{F}]}=1.5886$ & $D_{[\mathrm{FO}]}=1.6316$ & $D_{[\mathrm{FOM}]}=1.6899$ \\
Difference $\left(D_{[\mathrm{Diff}]}\right)$ & & - & 0.043 & 0.0583 \\
Relative to whole $(\%)$ & & 85 & 6 & 9 \\
\hline & & & & \\
\hline
\end{tabular}

(relative to the whole façade) of materiality (14\%). This outcome is a product of the large angled roof over the entry, which is a simple form with limited or no ornamentation, but with extensive material joints. This roof, with its low eaves and five semi-domes (also with expressed joints), does not have an equivalent on any other façade, and only its shorter dimension can be seen on the north east and south west elevations.

The remainder of the three elevations have a much higher level of consistency. In particular, the north east and south west elevations-being opposite sides of a partially symmetrical building-have a degree of similarity. In both cases form accounts for between 85 and $86 \%$ of the complete measurement, ornament adds only $6 \%$ to both facades, and materiality between 8 and $9 \%$. The differences between the two facades are primarily caused by two minor features. First, more of the lower section of the minaret is visible in the south west elevation, and second, the kulliye wall in the north east elevation features additional ornament associated with the banded wall of the madrasa.

Overall, the form-related properties of the Kılıç Ali Paşa Mosque account for between 78 and $86 \%(\mu=83.75)$ of the complete visual impact of the architecture, whereas ornament is between 6 and $8 \%(\mu=6.5)$ and materiality makes up between 8 and $14 \%(\mu=10.25)$. These results support past scholarly propositions 
Table 3 Final results for the Kılıç Ali Paşa Mosque

\begin{tabular}{|c|c|c|c|c|c|c|}
\hline Layer & Factor & $\begin{array}{l}\text { North west } \\
\text { elevation }\end{array}$ & $\begin{array}{l}\text { North east } \\
\text { elevation }\end{array}$ & $\begin{array}{l}\text { South east } \\
\text { elevation }\end{array}$ & $\begin{array}{l}\text { South west } \\
\text { elevation }\end{array}$ & $\begin{array}{l}\text { Mean } \\
(\mu)\end{array}$ \\
\hline \multirow[t]{3}{*}{ Form } & $D_{[F]}$ & 1.5558 & 1.5886 & 1.6038 & 1.5767 & 1.5812 \\
\hline & $D_{\text {[Diff }]}$ & - & - & - & - & - \\
\hline & $\begin{array}{c}\% \text { Relative } \\
\text { to whole }\end{array}$ & 78 & 85 & 86 & 86 & 83.75 \\
\hline \multirow[t]{3}{*}{ Form + ornament } & $D_{[F O]}$ & 1.6137 & 1.6316 & 1.6489 & 1.6148 & 1.6273 \\
\hline & $D_{[\text {Diff }]}$ & 0.0579 & 0.0430 & 0.045 & 0.0381 & 0.046 \\
\hline & $\begin{array}{c}\% \text { Relative } \\
\text { to whole }\end{array}$ & 8 & 6 & 6 & 6 & 6.5 \\
\hline \multirow{3}{*}{$\begin{array}{l}\text { Form, } \\
\text { ornament }+ \\
\text { materiality }\end{array}$} & $D_{[F O M]}$ & 1.7122 & 1.6899 & 1.723 & 1.6705 & 1.6989 \\
\hline & $D_{[\text {Diff }]}$ & 0.0985 & 0.0583 & 0.0741 & 0.0575 & 0.0721 \\
\hline & $\begin{array}{c}\% \text { Relative } \\
\text { to whole }\end{array}$ & 14 & 9 & 10 & 8 & 10.25 \\
\hline
\end{tabular}

Table 4 Results for the Süleymaniye Mosque

\begin{tabular}{|c|c|c|c|c|c|c|}
\hline Layer & Factor & $\begin{array}{l}\text { North west } \\
\text { elevation }\end{array}$ & $\begin{array}{l}\text { North east } \\
\text { elevation }\end{array}$ & $\begin{array}{l}\text { South east } \\
\text { elevation }\end{array}$ & $\begin{array}{l}\text { South west } \\
\text { elevation }\end{array}$ & $\begin{array}{l}\text { Mean } \\
(\mu)\end{array}$ \\
\hline \multirow[t]{3}{*}{ Form } & $D_{[F]}$ & 1.677 & 1.688 & 1.598 & 1.674 & 1.6592 \\
\hline & $D_{\text {[Diff }]}$ & - & - & - & - & - \\
\hline & $\begin{array}{l}\text { \% Diff. } \\
\text { relative to } \\
\text { whole }\end{array}$ & 87 & 89.6 & 80.8 & 87.3 & 86.175 \\
\hline \multirow[t]{3}{*}{ Form + ornament } & $D_{[F O]}$ & 1.689 & 1.702 & 1.638 & 1.691 & 1.68 \\
\hline & $D_{[\text {Diff }]}$ & 0.012 & 0.014 & 0.04 & 0.017 & 0.02 \\
\hline & $\begin{array}{l}\text { \% Diff. } \\
\text { relative to } \\
\text { whole }\end{array}$ & 1.2 & 1.4 & 4 & 1.7 & 2.075 \\
\hline \multirow{3}{*}{$\begin{array}{l}\text { Form, } \\
\text { ornament }+ \\
\text { materiality }\end{array}$} & $D_{[F O M]}$ & 1.807 & 1.792 & 1.79 & 1.801 & 1.7975 \\
\hline & $D_{[\text {Diff }]}$ & 0.118 & 0.09 & 0.152 & 0.11 & 0.117 \\
\hline & $\begin{array}{l}\% \text { Diff. } \\
\text { relative to } \\
\text { whole }\end{array}$ & 11.8 & 9 & 15.2 & 11 & 11.75 \\
\hline
\end{tabular}

which suggest that ornament plays only a minor role in Sinan's architecture in comparison to the importance of form and materiality.

One of the benefits of measuring architecture in this way is that two or more buildings may be mathematically compared. Using past published fractal dimension measures for Sinan's earlier and larger Süleymaniye Mosque and kulliye (Ediz and Ostwald 2012), it is possible to quantify the differences between the two in terms of the relative presence of geometry associated with form, ornament and materiality (Tables 4, 5). 
Table 5 Comparison of Results between Kılıç Ali Paşa Mosque and Süleymaniye Mosque

\begin{tabular}{|c|c|c|c|c|c|c|}
\hline Layer & Factor & $\begin{array}{l}\text { North west } \\
\text { elevation }\end{array}$ & $\begin{array}{l}\text { North east } \\
\text { elevation }\end{array}$ & $\begin{array}{l}\text { South east } \\
\text { elevation }\end{array}$ & $\begin{array}{l}\text { South west } \\
\text { elevation }\end{array}$ & $\begin{array}{l}\text { Mean } \\
(\mu)\end{array}$ \\
\hline \multirow[t]{3}{*}{ Form } & $\begin{array}{l}\text { Kılıç Ali Paşa } \\
D_{[\mathrm{F}]}\end{array}$ & 1.5558 & 1.5886 & 1.6038 & 1.5767 & 1.5812 \\
\hline & $\begin{array}{l}\text { Süleymaniye } \\
D_{[\mathrm{F}]}\end{array}$ & 1.677 & 1.688 & 1.598 & 1.674 & 1.6592 \\
\hline & $\% \operatorname{Diff}_{[\mathrm{F}]}$ & 12.12 & 9.994 & -0.58 & 9.73 & 7.8 \\
\hline \multirow[t]{3}{*}{ Form + ornament } & $\begin{array}{l}\text { Kılıç Ali Paşa } \\
D_{[\mathrm{F}+\mathrm{O}]}\end{array}$ & 1.6137 & 1.6316 & 1.6489 & 1.6148 & 1.6273 \\
\hline & $\begin{array}{l}\text { Süleymaniye } \\
D_{[\mathrm{F}+\mathrm{O}]}\end{array}$ & 1.689 & 1.702 & 1.638 & 1.691 & 1.68 \\
\hline & $\% \operatorname{Diff}_{[\mathrm{F}+\mathrm{O}]}$ & 7.53 & 7.04 & -0.109 & 7.62 & 5.27 \\
\hline \multirow{3}{*}{$\begin{array}{l}\text { Form, } \\
\text { ornament }+ \\
\text { materiality }\end{array}$} & $\begin{array}{c}\text { Kılıç Ali Paşa } \\
D_{[\mathrm{F}+\mathrm{O}+\mathrm{M}]}\end{array}$ & 1.7122 & 1.6899 & 1.723 & 1.6705 & 1.6989 \\
\hline & $\begin{array}{c}\text { Süleymaniye } \\
D_{[\mathrm{F}+\mathrm{O}+\mathrm{M}]}\end{array}$ & 1.807 & 1.792 & 1.79 & 1.801 & 1.7975 \\
\hline & $\% \operatorname{Diff}_{[\mathrm{F}+\mathrm{O}+\mathrm{M}]}$ & 9.48 & 10.2 & 6.7 & 13.05 & 9.86 \\
\hline
\end{tabular}

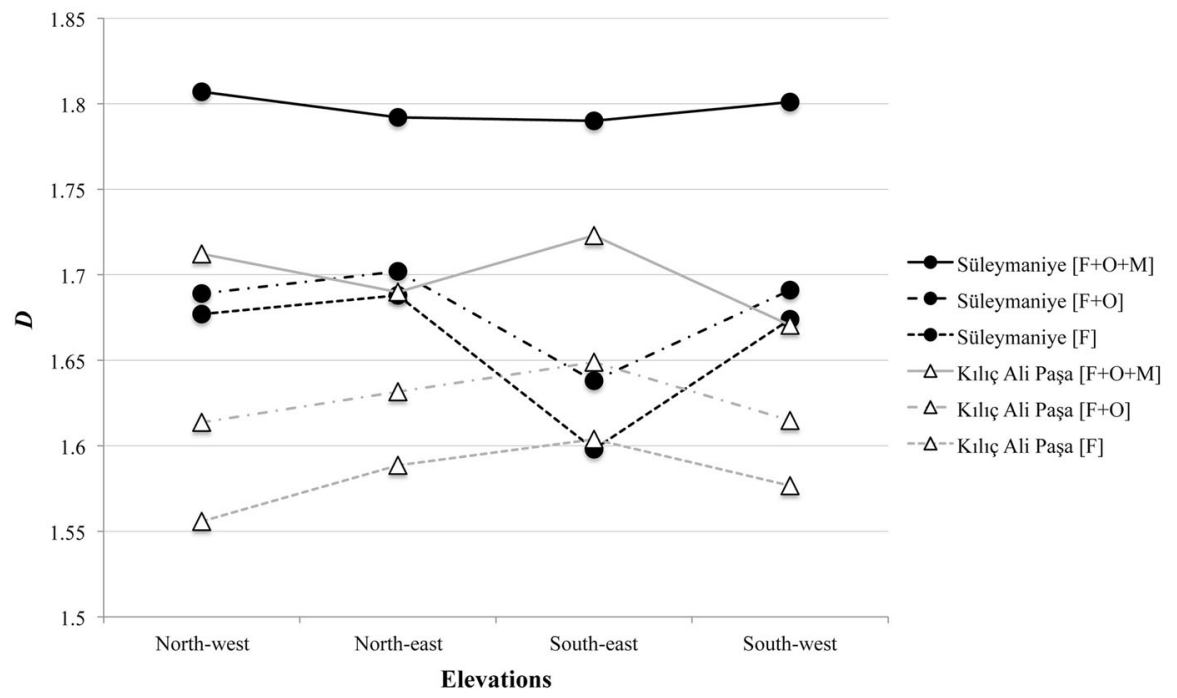

Fig. 5 Fractal dimension $(D)$ measures for façade layers of the Kılıç Ali Paşa Mosque and the Süleymaniye Mosque

When comparing absolute values for these designs, the characteristic formal complexity of the Süleymaniye Mosque is typically higher than that of the Kılıç Ali Paşa Mosque (Figs. 5, 6). The complete combination of form, ornament and materiality in the Süleymaniye Mosque is generally in the order of $10 \%$ $(\mu=9.86 \%)$ more visually complex than the equivalent combination in the Kılıç Ali Paşa Mosque. Whereas the south east elevations of these buildings both possess 


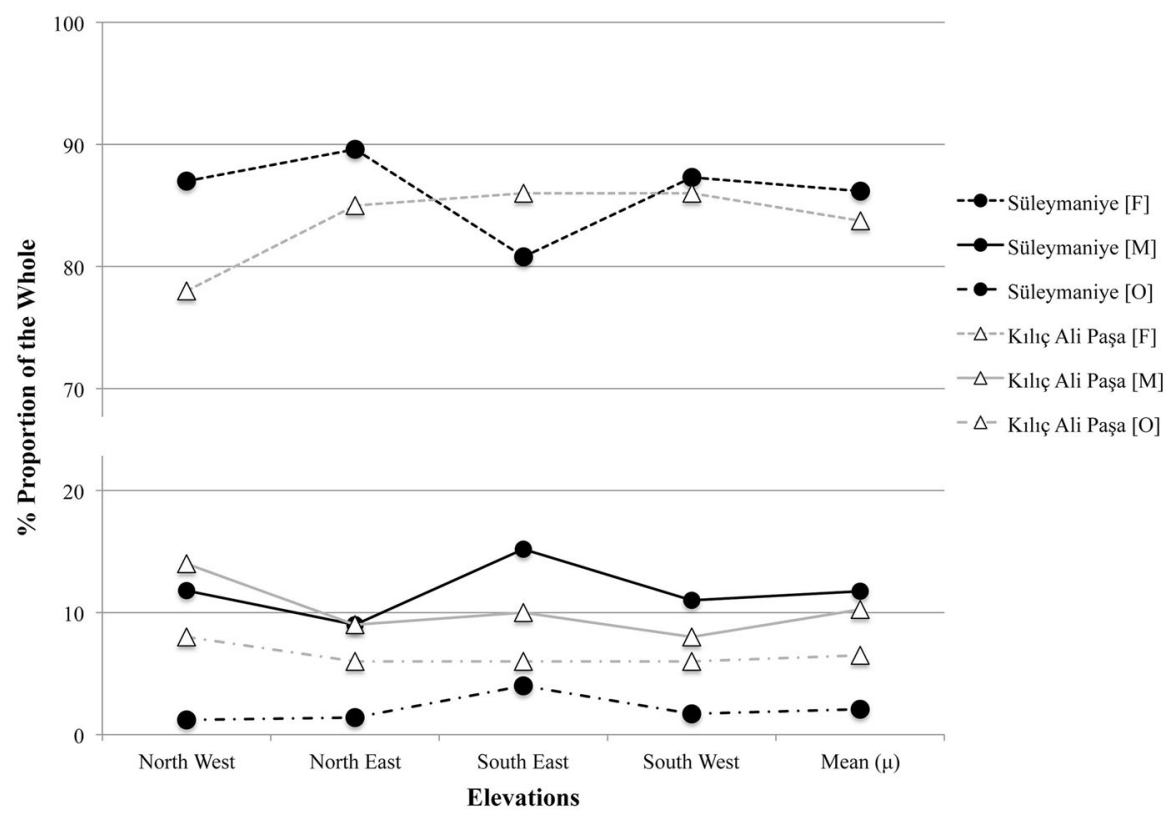

Fig. 6 Proportion of the façade detail generated by form, ornament or materiality in the Kılıç Ali Paşa Mosque and the Süleymaniye Mosque (note truncated $y$ axis scale)

similar levels of geometric complexity for form $\left(\% \operatorname{Diff}_{[\mathrm{F}]}=-0.58\right)$ and the combination of form and ornament $\left(\operatorname{Diff}_{[\mathrm{F}+\mathrm{O}]}=-0.109\right)$, the extent of material jointing in the walls, roofs and minarets in the Süleymaniye Mosque is higher $\left(\% \operatorname{Diff}_{[\mathrm{F}+\mathrm{O}+\mathrm{M}]}=6.7\right)$ (Fig. 7). For the remainder of the elevations, and especially the longer elevations, the Süleymaniye Mosque is more formally complex with differences of between 9.73 and $12.12 \%$ for the form layer, and between 9.48 and $13.05 \%$ for the form, ornament and materiality layer.

\section{Conclusion}

By measuring both the absolute and relative importance of form, ornament and materiality in Sinan's Kılıç Ali Paşa Mosque it is possible to test, for the first time, multiple claims that have been made about the visual properties of the design. The results derived from the façade measures developed in the present paper typically confirm the intuitive reading offered by scholars and historians who argue that the building is more reliant on form than on ornament for its physical presence and that its architectonic character (its materiality and construction) are critical to its overall appearance.

When comparing the results for the Kılıç Ali Paşa Mosque with Sinan's midcareer masterwork, the Süleymaniye Mosque, it is apparent that the earlier work is both more visually complex and has a stronger material presence. Another observation is that there is a more consistent relationship between the three layers of 

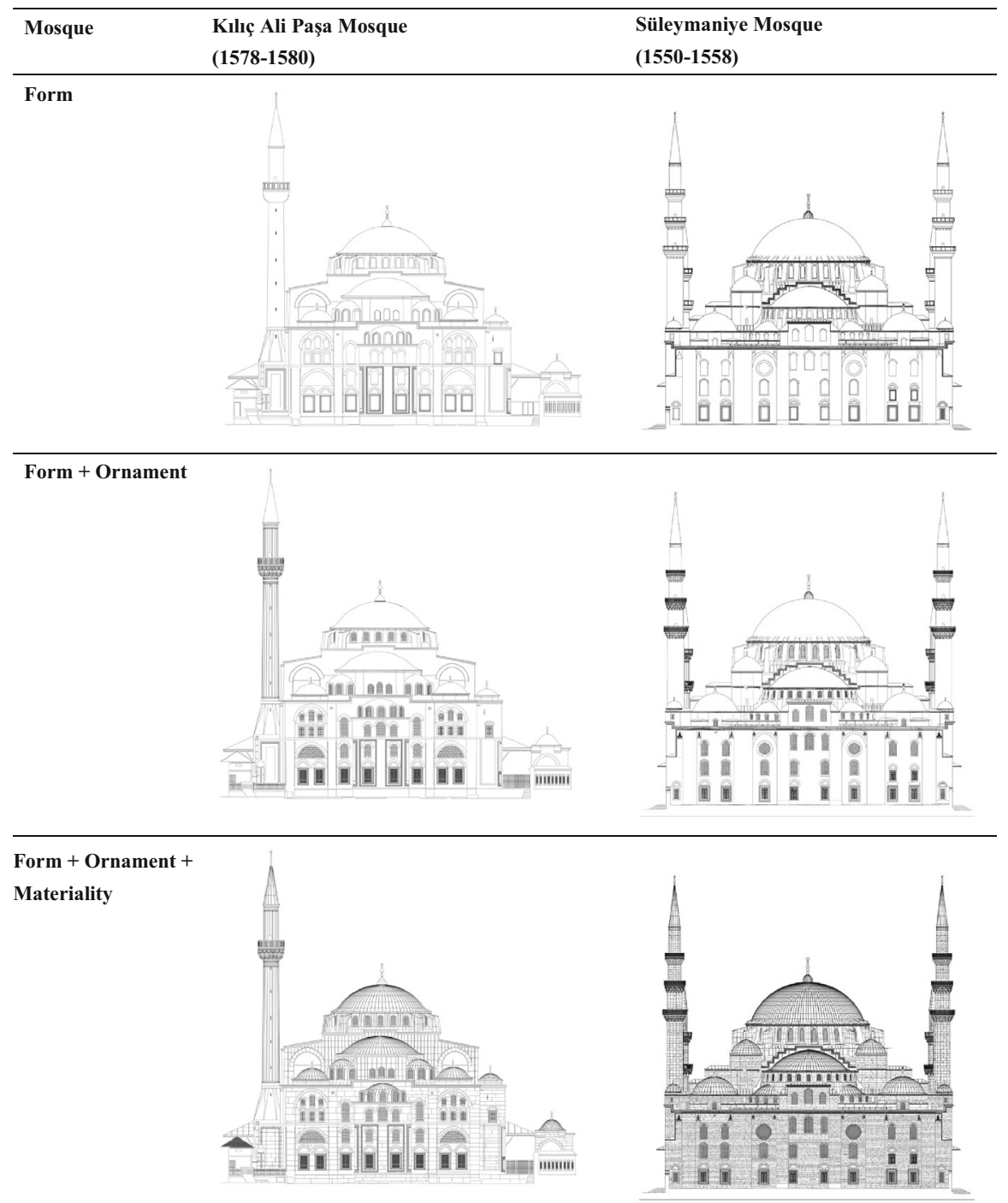

Fig. 7 Comparison: south east elevations of the Kılıç Ali Paşa Mosque and the Süleymaniye Mosque

information in the Kılıç Ali Paşa Mosque than in the Süleymaniye Mosque. How this could be interpreted is open to debate. Perhaps by returning to the form of the Hagia Sophia for inspiration Sinan was able to produce a more consistent or balanced composition (where the pattern in the relationship between form, ornament and materiality is stronger), than in the Süleymaniye Mosque.

Whether these mathematical results can be extrapolated to suggest something further about Sinan's changing language of design — and the trend towards simpler forms - is uncertain. A larger set of works, each similarly measured and analysed, 
would be required to construct such an argument and even then, the data would have to be carefully interpreted to take into account factors such as siting conditions, political imperatives, labour and material availability, all of which are also known to have shaped Sinan's architecture.

Acknowledgments The survey drawings for the Kılıç Ali Paşa Mosque were provided by the Istanbul Directorate of Foundations. ArchImage Software is by Steven Nicklin, Michael Ostwald, Stephan Chalup and Josephine Vaughan. An ARC Fellowship (FT0991309) and an ARC Discovery Grant (DP1094154) supported this research.

\section{References}

Batty, Michael, and Paul Longley. 1994. Fractal cities: a geometry of form and function. New York: Academic Press.

Bechhoefer, William, and Marilyn Appleby. 1997. Fractals, music and vernacular architecture: an experiment in contextual design, in critical methodologies. Study of traditional environments. Vol 97, Berkeley: University of California.

Bovill, Carl. 1996. Fractal geometry in architecture and design. Basil: Birkhauser.

Burkle-Elizondo, Gerardo. Nicoletta Sala, and Ricardo Valdez-Cepeda. 2014. Geometric and complex analyses of maya architecture: some examples. In Architecture and mathematics from antiquity to the future: volume I, ed. Kim Williams, and Michael J. Ostwald, 113-126. Basil: Birkhauser.

Burelli, Augusto Romano. 1988. La Moschea di Sinan/Sinan's Mosque. Venezia: Cluva Editrice.

Camastra, F. 2003. Data dimensionality estimation methods: a survey. Pattern Recognition 36: 2945-2954.

Ediz, Özgür, and Michael J. Ostwald. 2012. The Süleymaniye Mosque: a computational fractal analysis of visual complexity and layering in Sinan's Masterwork. ARQ Architectural Research Quarterly 16(2): 171-182.

Erzen, Jale. 2004. Sinan Ottoman architect: an aesthetic analysis. Ankara: Middle East Technical University.

Freely, John. 1992. Sinan: architect of Suleyman the Magnificent and the Ottoman Golden Age. London: Thames and Hudson.

Foroutan-Pour, K., P. Dutilleul, and D.L. Smith. 1999. Advances in the implementation of the boxcounting method of fractal dimension estimation. Applied Mathematics and Computation. 105(2): $195-210$.

Goodwin, Godfrey. 1971. A history of Ottoman architecture. London: Thames and Hudson.

Gözübüyük, Gaye. Gülen Çağdaş, and Özgür Ediz. 2006. Fractal based design model for different architectural languages. In The architecture co-laboratory game set and match II: on computer games, advanced geometries, and digital technologies, ed. K. Oosterhuis, and L. Feireiss, 280-287. Rotterdam: Episode Publishers.

Günay, Reha. 2009. Sinan: the architect and his works. Istanbul: Yapi Endüstri Merkezi Yayinlari/ Mimarlik Dizisi.

Huang, Q., J.R. Lorch, and R.C. Dubes. 1994. Can the fractal dimension of images be measured? Pattern Recognition 27(3): 339-349.

Kuban, Doğan. 1987. The style of Sinan's domed structures. Muqarnas 4: 72-97.

Kuban, Doğan. 1997. Sinan's Art and Selimiye. Istanbul: Economic and Social History Foundation.

Kuran, Aptullah. 1986. Mimar Sinan, Istanbul: Hürriyet Vakfi Yayinlari.

Lorenz, Wolfgang. 2003. Fractals and fractal architecture. Vienna: Vienna University of Technology.

Mandelbrot, Benoit B. 1977. Fractals: form, chance, and dimension. San Francisco: WH Freeman and Company.

Neal, F.Brent, and John C. Russ. 2012. Measuring shape. Boca Raton: CRC Press and Taylor \& Francis.

Necipoğlu, Gülru. 2005. The age of Sinan: architectural culture in the Ottoman Empire. London: Reaktion Books.

Ostwald, Michael J. 2013. The fractal analysis of architecture: calibrating the box-counting method using scaling coefficient and grid disposition variables. Environment and Planning B: Planning and Design 40: 644-663. 
Ostwald, Michael J., Vaughan Josephine, and Tucker Chris. 2008. Characteristic visual complexity: fractal dimensions in the architecture of Frank Lloyd Wright and Le Corbusier. In Nexus VII: architecture and mathematics, ed. Kim Williams, 217-232. Turin: Kim Williams Books.

Ostwald, Michael J., and Josephine Vaughan. 2013a. Representing architecture for fractal analysis: a framework for identifying significant lines. Architectural Science Review 56(3): 242-251.

Ostwald, Michael J., and Josephine Vaughan. 2013b. Limits and errors: optimising image pre-processing standards for architectural fractal analysis. Architecture Science (ArS) 7: 1-20.

Rogers, J.M. 2006. Sinan. Oxford: Oxford University Press.

Stratton, A. 1972. Sinan. New York: Charles Scribner's Sons.

Vaughan, Josephine, and Michael J. Ostwald. 2011. The relationship between the fractal dimension of plans and elevations in the architecture of Frank Lloyd Wright: comparing the Prairie style, textile block and Usonian Periods. Architecture Science (ArS) 4: 21-44.

Voss, Richard. 1986. Characterization and measurement of random fractals. Physica Scripta T13: 27-32.

Michael J. Ostwald is Professor and Dean of Architecture at the University of Newcastle, Australia. He is a Visiting Professor at RMIT University and a Research Fellow at SIAL (Melbourne). He has held past academic positions in the USA and Hong Kong and worked for architectural practices in Australia, the UK and the USA. Michael has a PhD in architectural theory and history and a higher doctorate (DSc) in design mathematics. He is Co-Editor in Chief of the Nexus Network Journal: Architecture and Mathematics (Springer) and on the Editorial Board of $A R Q$ (Cambridge) and Architectural Theory Review (Taylor \& Francis).

Özgür Ediz is Associate Professor and Vice Chair of the Architecture Department at Uludag University, Bursa, Turkey. He has a PhD in architectural design and theory titled 'A Fractal Based Approach in Early Design Phase'. His areas of interest are design computing, fractal based design, architectural design theories, design studio and generative design. Özgür has won awards in national and international architectural competitions and produced multiple articles and papers. 